Session No. 1421

\title{
Addressing the Workforce Shortage in the Construction Industry:
} A Vision

\author{
Erdogan M. Sener, Rex E. Ward \\ Indiana University-Purdue University Indianapolis/Ivy Tech State College Central Indiana
}

\section{Introduction}

It is common knowledge, substantiated by diverse sources and statistics, ${ }^{1,2}$ that the construction industry is currently experiencing a workforce shortage that will get worse in the coming years unless something is done about it and done soon. Even though the shortage will be felt in different ways, there is almost unanimous agreement that all the industry and country will be affected one way or other.

Various workforce organizations, such as AGC (Associated general Contractors), ABC (Associated Builders and Contractors), and other owner and/or contractor associations have started discussing the issue trying to come up with solutions. In line with the limited mission of these organizations, however, the measures being foreseen to overcome the shortage tend to concentrate on certain segments of the construction workforce rather than the whole. Some organizations are approaching the problem from the point of view of shortage of crafts or trades people such as electricians, framers, masons, etc., while others are approaching it from the point of view of technical or managerial personnel. Suggested measures for easing the shortage seem to exhibit polarity of workforce organizations in terms of being union or merit shop also.

\section{The Need}

Firstly, notwithstanding where the shortage seems to be at this point in time, it is the authors' belief that the issue should not be confined to the shortage of the workforce in specific segments of the industry only. The Indiana Career Cluster Guide ${ }^{2}$ is a listing of 14 career clusters that provides actual numbers of labor force supply and demand specific to Indiana career clusters. This document indicates a supply and demand gap of over 44,000 skilled trade workers needed to fulfill the market need in Indiana by the year 2005. Even though this document does not provide data for the balance of the construction workforce, it is only logical to foresee that the gap demonstrated by the data on the skilled trades component of the workforce will hold true for the balance of the employment categories in the industry also. Consequently, the shortage needs to be looked at from the perspective of the total workforce in the construction industry including the management, technical people, and the trades. Secondly, the issue should be addressed in such a way so that it is not influenced by the inherent difference in thinking between union and non-union workforce organizations. 
The question that needs to be addressed at this point, given the reality of a shortage and the prospects of it getting worse over time, is, where are the solutions that can ease the shortage or cure it going come from? Our opinion is that we need to look at the "non-traditional." Within the context of the problem-at-hand, the "non-traditional" should be in terms of "who" and "what", that is, both people and processes, namely:

- $\quad$ People from sectors of the population not proportionally represented in the current construction workforce, for example, females, blacks, Hispanics, and other minority

- $\quad$ People in industry apprenticeship programs not necessarily leading to a degree or credential (for technical or managerial workforce in the industry)

- $\quad$ New and emerging technologies and methods of instruction that will enable reaching populations groups not previously tapped for education/training in construction

- New and emerging technologies and methods of construction that will decrease the workforce need for certain segments of the industry (using robots for painting and welding steel, etc.)

- $\quad$ Growing your own and backfilling by advancing existing people into higher levels and starting new ones in the vacated positions to fill the vacuum.

This paper will concentrate more on the "who," that is, the people part of the issue rather than on "what", that is, the new or emerging technologies in the construction industry.

\section{Spectrum of Needs and Deficiencies}

Having identified where the people can possibly come from, one should be aware of the different needs and deficiencies these people may bring into the picture, namely:

- $\quad$ Literacy (some of the people that need to be targeted may not even be able to read and write in their native tongue)

- $\quad$ Language (teaching the new incomers not only the English language but also the workplace literacy in terms of the construction industry)

- $\quad$ Trade skills (teaching of vocational skills to crafts/trades people)

- Technical skills (for people that will serve in technician, engineer, architect, etc capacities)

- $\quad$ Management skills (for people that will manage the construction projects at diverse levels with diverse responsibilities)

\section{Methods and Characteristics of Delivery of Training and Education}

The above spectrum of training and education needs will have to be somehow addressed. In this process, the issues that need to be considered are the "how", "where' and the "pace" of these undertakings. For the "how" part, which are the means available for providing the needed education and training, the following are the possibilities :

- $\quad$ Short courses to address fast changing needs of employers in today's workplace

- Articulation from lower level of education/training to higher levels

- $\quad$ Distance/distributed learning

$\circ$ Job site learning (OJT - on the job training)

○ Correspondence courses 
$\begin{array}{ll}\circ & \text { Video/audio based delivery } \\ \circ & \text { CD-ROM based delivery } \\ \circ & \text { Internet/web based delivery }\end{array}$

Whatever the methodology one has to make sure that requisite quality is ascertained through appropriate accreditation of what is being done by relevant bodies in each area.

In terms of "where" such education and training can take place, the options are:

- A central community location

- $\quad$ At home

- On the job

- At the contractors location

- In the university or vocational college classroom

- Home or industry location + academic/vocational lab combination

In terms of "pace" of delivery, the options could be;

- $\quad$ Traditional classroom instruction (semester, quarter, etc)

- $\quad$ Flexible - self paced (CD-ROM, video, web, internet) instruction

- Open entry - open exit (modular curriculum with the assistance of a learning coach, flexible, self paced approach)

- $\quad$ Self-directed (same as the flexible approach except that it does not have a structure in terms of time, place, deadlines, etc., in delivery)

- $\quad$ Cafeteria approach (combination of all of the above in some fashion by the individual involved)

\section{The Model}

We thought that if we were to formulate the problem that this paper is trying to address as a construction project itself, this analogy would make it easier to better understand what is being prescribed. So, in this paper the workforce education problem for addressing the shortage of people in the industry has been looked at as a construction project in itself. It has the characteristics of a typical construction project, that is, the resources available for the construction project, the design phase of the project, the foundation of the structure, the structure itself, and the time schedule the project has to follow. The issues covered above are shown in their respective places in the construction project below:

- Resources: What are the resources and what resources can be leveraged to accomplish the project of education and training of the construction workforce at all levels?

- Design: What are the possible new sources of people? Who to target for recruitment to address the shortage?

- Foundation: Spectrum of needs and deficiencies on the part of the recruits that need to be addressed.

- $\quad$ Structure: Methods and characteristics of delivery.

- Time schedule: What needs to be done and in what order to accomplish the goals of workforce education? 


\section{Industry Input}

The above model was presented at the Educators' Conference meeting in Indianapolis in September 1999 co-hosted by AGC and IUPUI Department of Construction Technology and the following questions were posed to the audience composed of contractors, subcontractors, educators, and AGC representatives:

- Do you think the construction industry needs to undertake the tasks mentioned above in relation to the problem at hand in cooperation with appropriate partners?

- Who is going to lead/chair these initiatives and what will be the framework of cooperation?

- How can we, all parties that have a stake in the solution of the problem, collectively support the solution and what kinds of support are needed?

- Is this the right way to do it?

- What are the barriers to putting a system in place?

- Can we put the needs of the industry above some of the typical opinion differences between union and merit organizations?

- What activities do you think are on the critical path?

These items were discussed at length with everybody agreeing that this is the right way to do it and seeking more guidance from the educational and training institutions as to what would be a good way of starting to do this. The authors' proposition will be described below after coverage of what resources are available to start the task.

\section{Resources}

In Indiana there are a lot of resources that could be put to use towards solution of this problem, namely:

- Academic programs leading to degrees or certificates in diverse areas of the construction industry and its related industries

- $\quad$ Articulated programs between vocational colleges and universities

- $\quad$ Articulations between vocational programs and apprenticeship programs

- $\quad$ The Indiana Plan for Equal Employment

- $\quad$ AGC Supervisory Training Program

- $\quad$ ABC Apprenticeship Programs

- $\quad$ Company-based training programs

- $\quad$ Hispanic centers/Community Centers

- Indiana Department of Workforce Development

\section{The Suggested Solution}

When the construction industry is looked at in a systems approach it is evident that the need for people in the industry should be matched to the process that educates and trains people for the industry. When the construction industry human resource need is matched against human resource development through a "pyramidal system" one realizes that the two hierarchy diagrams of need and resource are matched in a general sense. The problem of matching need to development lies in the disconnect between the various providers within the hierarchy and in 


\section{Construction Industry Human Resource Pyramid}

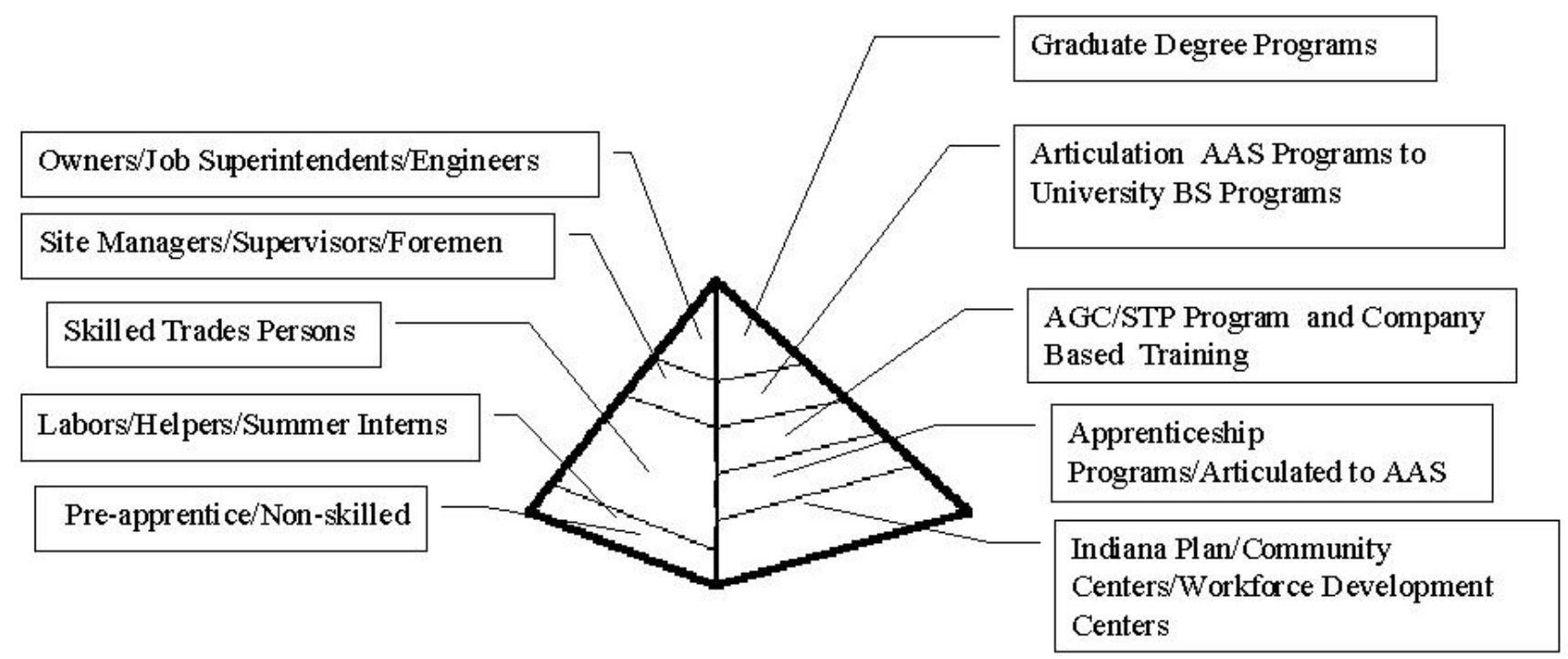

Industry Human Resource Demand Face

Human Resource Development Face

understanding the various upward career paths in the industry. The above diagram depicts the framework being prescribed for alleviating the shortage of the workforce in the construction industry. As an object of geometry and structure the pyramid has withstood the test of time and the authors think that it provides a good structure for addressing the problem at hand also. The "pyramidal system" anchors the workforce needs of the construction industry at different levels and the provision of training, in an articulated pathway. By looking at this issue in a "pyramidal" approach, the possibility of developing an articulated process for advancing through different career levels in the construction industry is possible. Not only does this system address the manpower shortage at all levels, rather than piecemeal solutions at craft level or other levels, it also ensures people to advance, as far as they want, through articulations put into place at appropriate levels and points.

\section{Conclusion}

Addressing the workforce shortage in the construction industry in its totality is possible by concentrating on the "non-traditional." This is non-traditional in the sense of people to tap to recruit, technologies to use for education of the people recruited, and the non-traditional ways of construction of the final product. A model/vision, that utilizes a bottom-up approach to the whole 
problem, needs to be used. The pyramidal model discussed above satisfies the conditions that the solution address all the workforce and not only the trades and be neutral in terms of union and non-union issues. This model makes the tasks facing the educational institutions, both academic and vocational, as well as the industry workforce organizations, clear. It provides a systems approach and structure to the problem in terms of determining, what needs to be done, by whom, and the governing relationships, so that we can look at this undertaking as a construction project and bring it to a successful completion.

\section{Bibliography:}

1. The Business Roundtable Construction Cost Effectiveness Task Force, Confronting the Skilled Construction Work Force Shortage- A Blueprint for the Future, October, 1997.

2. Indiana Occupational Information Coordinating Committee, Indiana Department of Workforce Development, Indiana Career Cluster Guide, 2 nd edition, 1990-2005.

\section{ERDOGAN M. SENER}

Professor and Chairman at the Dept. of Construction Technology of Purdue School of Eng. \& Tech'y at IUPUI. B.S. Civil Eng., Middle East Tech'l Univ.; M.S. Civil Eng. Michigan State Univ. He has over 12 years of international industrial experience in design and construction in architectural and civil construction and has been in engineering and technology education for more than 18 years. Member of ASCE, ASEE, ACI and is a registered Professional Engineer in Indiana. Prof. Sener was awarded numerous teaching awards including the Indiana University President's Award for Distinguished Teaching in 1993 and the IUPUI Chancellor's Award for Excellence in Teaching in 1994.

\section{REX E. WARD}

Director, Business and Industry Training for Ivy State College of Central Indiana providing corporate training services. B.S. in Business Adm., Tri-State Univ. He has 18 years of experience in providing training and human resource development. He led the development of the College Associate of Applied Science-Apprenticeship Technology degree programs that are articulated with apprenticeship programs across Indiana. He is a member of the Construction Industry Coalition that plans the strategy for construction industry skill standards. He has led the research teams that performed the update to the Indiana Electronics Manufacturing Skill Standards Proficiency guidelines He is a founding member of the executive committee for the yearly Workplace Learning Conference. He was recognized as the "Employment and Training Professional" in 1993 by the Indianapolis Private Industry Council. 